\title{
JUGGLING WORK AND PRIVATE LIFE IN TELEWORKING DURING THE EPIDEMIC COVID-19
}

\author{
Tjaša Rendić ${ }^{1}$ \\ Andrej Kovačič ${ }^{2}$ \\ Andrej Raspor ${ }^{3}$
}

DOI: https://doi.org/10.31410/ITEMA.S.P.2020.125

\begin{abstract}
In 2020, the world was hit by the Covid-19 epidemic and the countries made different decisions on when and how to adopt adequate measures. One of them was teleworking; many people stayed at home where they worked and at the same time took care of their family members and assisted their school-age children.

After one month of working from home, the respondents assessed that their family members had a better understanding of the concept of working from home. Besides, the respondents were more organised for this type of work and took care of their school-age children. The fear of losing their job has also reduced, but they were more concerned about salary cuts.

The selection of findings and measures could become a guide for employees in order to help them balance private life and work and thus manage stress when working from home.
\end{abstract}

Keywords: Teleworking, Stress management, Stress related to teleworking, Contemporary technologies, Covid-19 epidemic.

\section{INTRODUCTION}

$\mathrm{O}$ n 31 December 2019, the WHO was informed of several pneumonia cases of unknown cause in the Chinese city of Wuhan. At the point of writing this study, the coronavirus has hit societies around the world hard and the countries continue to recommend their citizens to stay at home as much as possible. The countries have also imposed restrictions on social activities, whereas the severity of restrictions varies among countries (World Health Organization, 2020). In Slovenia, where the current study is being conducted, the restrictions were introduced on 13 March 2020, whereas the infectologists called for measures to restrict public life. All EU member states have adopted similar measures to those in Slovenia and are gearing up for a potential further spread of the virus. Slovenia has, on a proposal from infectologists, already taken the following measures: (1) closure of educational institutions, (2) restrictions on border crossings with Italy, (3) restrictions on public life, (4) work from home (Government Communication Office, 2020).

At the point of writing of the present article, the amount of research on the topic of telework during the Covid-19 epidemic is limited for now. However, right at this time, many articles are being created and more of them will be generated in the coming years. Some research was done on home-based telework in the wake of natural disasters, where it was shown that individual home-situations and manager involvement were important factors in the success of telework (Donnelly \& Proctor-Thomson, 2015). More recent studies focus on the researches on the

ERUDIO master's student, Slovenia

Fakulteta za medije, Slovenia

School of Advanced Social Studies Nova Gorica, Slovenia 
impact of distance learning (Di Domenico, Pullano, Pullano, Hens, \& Colizza, 2020), whereas other works explore more along the lines of the impact of telecommuting on productivity (Okubo, 2020), Internet security (Abukari \& Bankas, 2020) and also the experiences of teleworking (Baert, Lippens, Moens, Weytjens, \& Sterkens, 2020).

With this said, the research question, that this study will be looking to answer, is: "How to balance private and work obligations when working from home during the Covid-19 epidemic?"

\section{THEORETICAL BACKGROUND}

\section{a. Organisation of work and teleworking}

Globalisation dictates changes; there are cultural and ethical changes on the one hand and information and communication technology on the other. Down through history, this has already happened several times.

In the light of the current situation, it is crystal clear that different forms of a network organisation will assert themselves more significantly in the future (modular network, virtual network/organisation, etc.). A fast-changing business environment and competition require constant development and adjustment. As a consequence, new organisational forms are emerging in business practice (Fann Thomas, n.d.). Virtual organisation as one of modern organisational forms goes beyond the limits of a traditional organisation. The importance of physical structure is reduced; therefore, virtual organisation enables in particular flexibility and responsiveness. It is mainly based on information and telecommunication technology but also on the work where physical movement is required. Virtual teams represent a new development stage of teamwork as they enable the members of a team, through the use of appropriate technology, to have interactions beyond the boundaries of an organisation, time and space. In practice, we meet only a few virtual teams, whereas conventional teams, which make use of virtual elements, are becoming increasingly recognised. The mentioned data also indicates the direction of teamwork's development in the future. The virtual organisation, which uses virtual teams in its activities, is only one of the possible modern organisational forms (Raspor \& Nežič, 2020).

The emergence of the Covid-19 should be seen in the light of the health aspect. Besides, the impact of the virus, which will be seen in economic crisis, is not negligible. In fact, no two crises are equal and it is also very difficult to predict in advance all their elements. Nevertheless, exceptional circumstances always bring the need to change an organisation. Identifying the beginning of the crisis period in organisation, is of crucial importance. A company needs to have a prepared strategy on how it will operate in troubled times. Every contingency plan must also include a perspective on the future.

Telecommuting can be both useful and challenging; useful in a way that you can work at the desired location and challenging in a way that certain questions can raise regarding team building, group participation and communication. Remote jobs offer many benefits, whereas a lot of discipline and time management are required for success. Nevertheless, innovative technology offers a wide range of tools with which telecommuting can become a less demanding environment. The technology enables individuals to perform the same work from everywhere. The companies' owners, therefore, implement technologies in order to help their co-workers carry out work assignments in time and encourage team spirit. Certainly, 
telecommuting requires the right tools for time management that direct us from urgent to important tasks and keep us regularly informed about where we stand on our way to reach a certain goal (Necessary Tools Checklist To Plan Your Time Working Remotely, n.d.).

\section{b. Tension between work and private life}

The main points of home-based telework are the blurred lines between work and non-work. The pros and cons of the flexibility of telecommuting are related to the distribution of work hours as well as to the social and personal impact of not having to physically be at work. But when it comes to telework during the Covid-19, the conditions are not the same as for teleworking under normal circumstances. More precisely, during this coronavirus period, the workers have to fulfill many tasks other than work assignments. So, the individuals who work remotely are in a tough position. Teleworking is heavily encouraged not only by employers but also by the authorities with its recommendations. Hence, remote work is not the workers' choice as they are forced to work in such a way. Consequently, telecommuting might be experienced differently than when it is chosen freely (World Health Organization, 2020).

"Nowadays, we tend to aim to create a balance between family and work responsibilities. Broader researches indicate that people who are aware of the balance between work and life roles are more satisfied with life and report on better physical and mental health" (Haar, Russo, Sune, \& Olliver-Malateere, 2014; Kopitar, 2020).

The impact of coronavirus will be felt at all levels; therefore, the management system will certainly have to be changed. The leaders will have to master more techniques regarding the remote management supervision of co-workers since more telecommuting itself is expected in the future. Such a working system will suit very well some co-workers (at least for a while), whereas to others, it will cause great stress. The leaders can also react differently to new circumstances. In this period, it is their job to organise work and lead co-workers. They must also ensure that co-workers can recognise and respond to potential problems in terms of other co-workers' mental health and reducing all negative impacts of work from home. A sudden change in the way of leading can be very difficult for leaders. They may be concerned about disturbances in the process for which they are in charge. On the one hand, some believe that leaders must be physically present in order to be good leaders; on the other hand, other people do not trust the co-workers whom they cannot see.

In the light of new circumstances, it is recommended that the leaders of the future - all, without exception - become familiar with a new way of work and leadership regardless of the leadership style that has been in use up to now. Effective work from home largely (according to the Gallup research from 2020, even up to 70\%) depends on the engagement of leaders and their support to co-workers. Based on the finding above, we will provide instructions that will help you to better lead the co-workers who work from home (Gallup, 2020; Larson et al., 2020; Forbes, 2019).

Although working from home is the best scenario for many co-workers in the given situation, many leaders may have a hard time coping with such a form of work. They can feel as if they do not have any control over telecommuting or they may find that it is a challenge to maintain the same level of trust with a remote working team. Nevertheless, that is the future of leadership and the leaders must adapt to it so that the situation will be functional for all concerned. Such situations will be (as we shall see later in this chapter) more and more frequent; therefore, we will have to get used to it. Remote team leadership is also an investment. At a time when co- 
workers are mainly left to themselves and have very little interaction with their co-workers and the leader, it is very important how they will maintain or perhaps even upgrade the relationships within their team and with the leader. Once things return to normal and the companies will operate as usual, it will be important with what energy will the co-workers come back to the workplace. In terms of their approach and attitude, the leaders can make a significant contribution so that the co-workers' constructive commitment to work can be the way it used to be before transition to telecommuting.

Hallin suggested: (1) A necessary adjustment to a digital way of working has been made. (2) Digital communication is used to supplement the usual need for physical social interaction, and it helps to do so but is not as socially fulfilling as regular social interactions. (3) The coronavirus outbreak has hurt social life within and outside of work. (4) The boundaries have become more blurred. (5) It is easier to structure the day to meet personal needs and goals. (6) The workdays are less varied. (7) The feelings of uncertainty regarding the future. (8) The Covid-19 epidemic has had personal negative effects and has caused negative emotions in people. (9) A new insight has been gained, especially when it comes to the viability of digital solutions, and adaptations to personal habits have been made (Hallin, 2020).

\section{c. School dismissals or closures}

During the Covid-19 period, a particular burden for people working from home was that children were also at home. School dismissal refers to the situation when a school campus remains open with administrative staff and teachers present while most children stay at home. School closure is a stricter intervention in which a school campus is closed for all children and all staff. (Fong et al., 2020). School closures can also have adverse impacts on ethical and social equity, particularly among vulnerable groups (e.g. low-income families), which could be ameliorated by dismissing classes but allowing some children to attend school for free school meals or to enable parents to go to work.

\section{d. Stress}

Staff management plays a very important role in organisation of work. Excessive requirements lead to stressful situations because a worker is no longer capable of dealing with them. The situation even becomes worse if a worker is not able to admit it. However, insufficient requirements can also be stressful for a highly qualified worker as he or she can feel superfluous, overlooked and useless. The manager must know how to organise work, make a fair distribution of work, recognise potential conflict situations and prevent them before breaking out (Tajnšek, 2020).

Deep-rooted gender norms on the division of roles in the household, regarding telecommuting, may aggravate gender inequality concerning housework and care for children. More exactly, an employee working from home can spend too much time on domestic work and childcare and it can come to multitasking, reduction in the quality of mother's work, and an increase of their stress in connection to their husbands (Lyttelton, Zang, \& Musick, 2020). Among those who prefer to telecommute, women are more likely to prefer teleworking for the sake of family responsibilities, stress reduction and having more time for themselves, whereas men often prefer telecommuting to get more work done (Mokhtarian, Bagley, \& Salomon, 1998). Certainly, the distribution of work among family members and a detailed schedule that includes activities are important for stress reduction. 


\section{METHODS}

A survey questionnaire was used for the research. It was made by using the $1 \mathrm{ka}$ online survey and submitted on 14 April 2020 via e-mail and was also published on social networks. The survey was available from 14 to 26 April 2020. The interval for conducting the survey was set for a short period to enable the respondents to experience the first days of quarantine to the greatest extent possible and to compare this period to the situation after one month of working from home. The first part of the questionnaire collected information on gender, age, education, profession, and marital status. The second part of the questionnaire included statements on information technology. The third part consisted of questions about working from home. All questions were measured according to the 5-point Likert scale. By using the scale, the respondents expressed their level of agreement with individual statements. The questions related to stress when working from home were prepared by using a table with two scales because we wanted to show a comparison of experiencing stress after one week and one month of working from home. The e-mail containing the questionnaire was sent to 68 faculties, 24 primary schools, 53 companies, 16 adult education centres, 26 secondary schools, 18 libraries, 5 music schools, 13 museums and 9 business incubators. At the same time, the questionnaire was shared on Facebook and LinkedIn. The data was statistically analysed and tested using SPSS.

\section{a. Research Instrument}

The employees from 232 different organisations were invited to take part in our random sample. 727 employees replied to the survey questionnaire of which 631 worked from home during the Covid-19 epidemic. The level of stress after the first week and after the first month of working from home was compared. The obtained replies were analysed by using SPSS.

We adjusted the questions to the Slovenian population as well as tested and revised the questionnaire before the final version.

To test the questionnaire, we conducted a preliminary research small-scale analysis (five samples) and revised the disparity of answers as well as the general understanding of the questions.

The first part of the questionnaire collected information on gender, age, education, profession, and marital status. The second part of the questionnaire included statements on information technology. The third part consisted of questions about working from home. All questions were measured according to the 5-point Likert scale.

\section{b. Demographic data}

Through the random sampling procedure, we managed to collect opinions from 727 respondents (605 females and 122 males). Women participating in the survey represent $0.15 \%$ of the working-age population, while the share of men is $0.02 \%$. The sample gender ratio reflected the organisation gender ratio 8:2 in favour of females. Sampled employees were almost equally divided into two age groups: 26 to 35 years and 36 to 45 years. There were $61 \%$ with a university degree in the sample.

To summarise the socio-demographic data of the research, the participants were mostly women from the age groups of 26-35 and 36-45 and had a university degree. The majority of the respondents were employed in schools, offices, and health care systems and had up to five 
years of work experience. $85 \%$ of respondents were married and $33 \%$ took care of their schoolage children.

\section{c. Hypotheses}

Based on the review of the theories, we set the following research question: "How to balance private and work obligations when working from home during the Covid-19 epidemic?"

We set up the following hypotheses:

H1: Stress as a result of work from home also affects the individual's private life.

The set hypothesis was the basis for the following statements: In the period of working from home due to the Covid-19, I have experienced stress; Because of work from home, the number of conflicts between me and my family has increased; As a result of adjustments in relation to work from home, it has also come to tensions in private life.

$\mathrm{H} 2$ : Due to juggling private and working life, the individual working from home is more exposed to stress.

In order to obtain the results of the mentioned hypothesis, we observed the respondents who worked from home in the epidemic period and also the respondents who did not work. The comparison was done in terms of the feeling of stress at work in both groups.

\section{RESULTS}

H1: Stress as a result of work from home also affects the individual's private life. With this hypothesis, we wanted to determine the correlation between stress as a result of work from home and the conflicts in private life. The questionnaire contained three statements (see table 1) related to the set hypothesis: In the period of working from home due to the Covid-19, I have experienced stress; Because of work from home, the number of conflicts between me and my family has increased; As a result of adjustments in relation to work from home, it has also come to tensions in private life.

Table 1. Description of variables - hypothesis $1(n=631)$

\begin{tabular}{|l|c|c|c|c|}
\hline Variable & Minimum & Maximum & Average & $\begin{array}{c}\text { Standard } \\
\text { deviation }\end{array}$ \\
\hline $\begin{array}{l}\text { Because of work from home, the } \\
\text { number of conflicts between me and } \\
\text { my family has increased. }\end{array}$ & 1 & 5 & 1.87 & 1.152 \\
\hline $\begin{array}{l}\text { In the period of working from home } \\
\text { due to the Covid-19, I have } \\
\text { experienced stress. }\end{array}$ & 1 & 5 & 3.35 & 1.413 \\
\hline $\begin{array}{l}\text { As a result of adjustments in relation } \\
\text { to work from home, it has also come } \\
\text { to tensions in private life. }\end{array}$ & 1 & 5 & 2.39 & 1.284 \\
\hline
\end{tabular}

\section{Source: Author's calculations}

In determining correlation, we combined the statements "Because of work from home, the number of conflicts between me and my family has increased" and "As a result of adjustments 
in relation to work from home, it has also come to tensions in private life" into a new variable "conflicts".

With the help of Pearson correlation coefficient (see table 2), we figured out the medium correlation of the mentioned two variables in the above case. In terms of stress present after the first week of working from home, there is a connection between stress at work from home and the conflicts in private life; $r=0,434, p(2$-sided $)<0,01$. In the employees who experienced stress after the first week of working from home, tensions and conflicts also appeared in their private life. Regarding the fact that the two variables are correlated, we can confirm the hypothesis.

Table 2. Pearson correlation coefficient between the variables "stress at work from home" and "conflicts in personal life - first week"

\begin{tabular}{|l|l|c|c|}
\hline \multicolumn{2}{|l|}{} & $\begin{array}{c}\text { stress_at_work_ } \\
\text { from_home_first_week }\end{array}$ & conflicts \\
\hline \multirow{3}{*}{$\begin{array}{l}\text { stress_at_work_ } \\
\text { from_home_first_week }\end{array}$} & $\begin{array}{l}\text { Pearson correlation } \\
\text { coefficient }\end{array}$ & 1 & $0.434 * *$ \\
\cline { 2 - 4 } & Importance (2-sided) & & 0.000 \\
\cline { 2 - 4 } & Total & 631 & 631 \\
\hline \multirow{4}{*}{ Conflicts } & $\begin{array}{l}\text { Pearson correlation } \\
\text { coefficient }\end{array}$ & $0.434 * *$ & 1 \\
\cline { 2 - 4 } & Importance (2-sided) & 0.000 & 631 \\
\cline { 2 - 4 } & Total & 631 & \\
\hline
\end{tabular}

**. Statistical importance at 0.01 (2-sided).

Source: Author's calculations

\section{H2: Due to juggling private and working life, the individual working from home is more exposed to stress.}

For the mentioned hypothesis, we observed the respondents who worked from home in the epidemic period and also the respondents who did not work. The comparison was done in terms of the feeling of stress at work in both groups. Table 3 shows descriptive statistics. The total number of people working from home during the epidemic is 631 , whereas the share of those not working from home and that answered to the given question is 93. In terms of agreeing with the statement, the arithmetic mean is 3.47 in the respondents who worked from home and 3.25 in those who did not, which demonstrates that in both cases it is close to the agreement with the grade 3 - "I somewhat agree". The standard deviance in those who did not work from home is in relation to the arithmetic mean greater than in those who did work from home.

Table 3. Descriptive statistics of hypothesis 2

\begin{tabular}{|l|c|c|c|c|c|}
\hline & $\begin{array}{c}\text { Work from } \\
\text { home }\end{array}$ & Number & $\begin{array}{c}\text { Arithmetic } \\
\text { mean }\end{array}$ & $\begin{array}{c}\text { Standard } \\
\text { deviance }\end{array}$ & $\begin{array}{c}\text { Std. error of } \\
\text { arithmetic mean }\end{array}$ \\
\hline $\begin{array}{l}\text { Work causes } \\
\text { stress to an } \\
\text { individual }\end{array}$ & YES & 631 & 3.47 & 0.892 & 0.036 \\
\cline { 2 - 6 } & NO & 93 & 3.25 & 1039 & 0.108 \\
\hline
\end{tabular}

Source: Author's calculations

With the use of Levene's test on differences between the two variances, we figured out that $p$ $>0.05$, therefore, we will retain the assumption of homogeneity of variances. The difference between the two samples can be generalised to the entire population with a $5 \%$ risk. 
In terms of T-test (see table 4), we obtained the result $\mathrm{p}<0.05(\mathrm{p}=0.030)$. On such a basis, we can conclude that the differences between the two arithmetic means are statistically important.

Table 4. T-test of hypothesis 2

\begin{tabular}{|l|l|c|c|c|c|c|}
\hline \multicolumn{2}{|l|}{} & $\mathrm{t}$ & $\begin{array}{c}\text { Degree of } \\
\text { freedom }\end{array}$ & $\begin{array}{c}\text { Statistical } \\
\text { importance } \\
\text { (2-sided) }\end{array}$ & $\begin{array}{c}\text { Average } \\
\text { difference }\end{array}$ & $\begin{array}{c}\text { Std. error } \\
\text { difference }\end{array}$ \\
\hline \multirow{2}{*}{$\begin{array}{l}\text { STRESS_ } \\
\text { work }\end{array}$} & $\begin{array}{l}\text { Equal } \\
\text { variances } \\
\text { assumed }\end{array}$ & 2.174 & 722 & 0.030 & 0.220 & 0.101 \\
\cline { 2 - 7 } & $\begin{array}{l}\text { Equal } \\
\text { variances not } \\
\text { assumed }\end{array}$ & 1.941 & 112.872 & 0.055 & 0.220 & 0.113 \\
\hline
\end{tabular}

Source: Author's calculations

On average, the employees who worked from home were more exposed to stress $(\mathrm{M}=3.47$, $\mathrm{SE}=0.036)$ than those who did not $(\mathrm{M}=3.25, \mathrm{SE}=0.108)$. Such difference is statistically important: $\mathrm{t}(722)=2.174, \mathrm{p}<0.05$, so the hypothesis can be confirmed.

\section{FUTURE RESEARCH DIRECTIONS}

If we want to be successful in stress management, we first have to understand the concept. The figure below (figure 1) shows the relations between work obligations that we perform at home. With that said, we have also provided the answer to the initial research question: "How to balance private and work obligations when working from home during the Covid-19 epidemic?"

Figure 1. Relations between work obligations that we perform at home

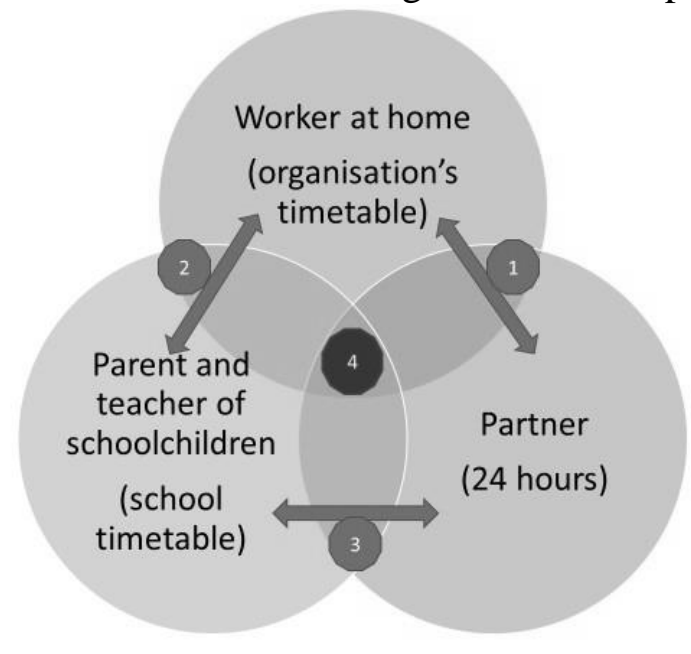

In this case, it is important to ask to what degree do we have a free hand in scheduling and who are the persons that we collaborate with. The more rigid the schedule and the more interactions we have with other co-workers, the bigger the gap (gap 1) between work and private obligations. In terms of work duties and obligations of schoolchildren, the situation is similar (gap 2). Here is particularly important when children have obligations and how autonomous they are in a way that they can fulfill the given responsibilities. The younger they are and the less they are informationally literate, the more help they need. It is also important how children 
distribute their mandatory presence and self-study. If we continue, the third gap (3) is seen between our private obligations and those of schoolchildren. This relates to housework, taking care of other household members (who are relatively able to take care of themselves) or of parents, etc. There are situations in which adaptations are not possible, e.g. emergency meetings, helping children with their work at a specific time, medical appointment, etc. If any of the mentioned instances occur, we need external aid in order to eliminate the gap.

In his contribution, Vičič (2020) presented the measures with which employers can help the employees with different psychological aspects, which may become manifest in the case of long-term work from home. These measures are human contact, informing, division of labour, maintaining predictability and safety, additional motivation mechanisms, and monitoring the mood of employees. In relation to that, the leaders must not forget to also take care of themselves. With the help of such measures, the employer can contribute to stress reduction in the working life of an individual and consequently in the individual's private life as well.

With a house full of children and working parents, it is important to be realistic about your working situation and to have the willpower it will take to succeed - that also means taking time to explain to your family what is happening. Being transparent about every family member's schedule can make it easier for children to understand when you are not available to them. Scheduling is vital, but when it comes to setting up your schedule, do not try to mimic your day at the office; it is important to acknowledge that the situation has changed; i.e. from office work to teleworking. Instead, create a daily plan for the entire family that includes work and school schedules, and also make it easily visible to everyone. For parents with younger children, consider an early morning work shift before "school hours" begin. With a couple of hours of work already under your belt, it makes it easy for you to take a break in the midmorning to help the children with their schoolwork. Creating opportunities for productivity is one option; if both parents work, divide up the day into blocks that give one parent space away from the children at a specific time. Identify your priorities regarding your work and focus on the essentials - all the unimportant stuff can wait. Figuring out how to make the best of the given situation rather than dwelling on its challenges might also make you more productive. Multiple studies show the positive link between happiness and productivity (DiMaria, Peroni, \& Sarracino, 2020; Ledford, 1999; Oswald, Proto, \& Sgroi, 2015). Under lockdown that could mean sneaking in an online yoga class with your child, finding time to play catch, or giving children a couple of extra hugs throughout the day. Avoid judging yourself - or others - on what you can get done each day. People at all levels of a company are adjusting to a new normal, including your boss (Dizik, 2020).

The epidemic has been some sort of a test of our abilities to adapt to a different way of working. Besides, every individual has had the time to check how much is he or she capable of switching between private and professional life. We have been given a chance to test what really means to work from home, which has been in operation for quite some time in some parts of the world.

The employees themselves can raise awareness of certain causes of stress and psychosocial risk factors in the workplace with the help of questions for self-assessment, e.g. in relation to the physical environment (too much noise, poor air quality, low/high temperature, powder), perception and experience of work in itself (satisfaction, difficulty, challenges, overburden with work assignments, role conflict, confounding factors, repetitive tasks, monotonous work, time pressure, norm, etc.), labour relations (bad interpersonal relations, lack of communication, mobbing, bullying, other behaviours of control and coercion). (Podgornik, 2020). 


\section{CONCLUSION}

What will tomorrow bring to us and with what challenges will be faced the employers, coworkers, and their leaders? What response will the school system give to these challenges? Artificial intelligence and industry 5.0 enable unexpected and extraordinary levels of development. Interconnecting man and machine will lead to an increase in virtual meetings and researches (Raspor \& Nežič, 2020).

It is expected that the actual events will enhance the development of industrial revolution 5.0, which will be based on autonomous integration. In doing so, we will probably reach the singularisation phase of man and machine. There are more and more advanced companies, which will be capable of overcoming such obstacles and combine knowledge from different fields. The fifth industrial revolution (industry 5.0) is, in the spirit of personalisation, oriented towards stronger and more qualitative integration of automation, human brain, and emotional intelligence (Raspor \& Nežič, 2020). The move from the fourth to the fifth industrial revolution will give more emphasis on the man's work in in the production and it will bring together the best from both worlds - people and machines - and it will also provide greater productivity. Monotonous, repetitive tasks will be carried out by mechanics, whereas people will open themselves to a creative side of the business. In doing so, greater responsibility will be entrusted with them and they will also have greater control over the system and consequently, the opportunity to raise the production quality. Fast nano processing and seemingly infinite memory, robots, drones, autonomous vehicles, and other machines will set us free from the boredom of everyday life and work and they will enable our mind to reach new heights (Blagajac, n.d.). On the other hand, an increasing amount of work will be performed from home. The companies must be aware of its pros and cons. Hence, they must appropriately train their employees so that they will efficiently work from home. However, the employees themselves must organise their work in a way that their family life will not suffer.

\section{REFERENCES}

Abukari, A. M., \& Bankas, E. K. (2020). Some cyber security hygienic protocols for teleworkers in COVID-19 pandemic period and beyond. International Journal of Scientific \& Engineering Research, 11(4), 1401-1407.

Baert, S., Lippens, L., Moens, E., Weytjens, J., \& Sterkens, P. (2020). The COVID-19 crisis and telework: A research survey on experiences, expectations and hopes.

Chan, D. (2020). How to make critical decisions amid Covid-19 pressures. Research Collection School of Social Sciences, Paper 3213.

Di Domenico, L., Pullano, G., Pullano, G., Hens, N., \& Colizza, V. (2020). Expected impact of school closure and telework to mitigate COVID-19 epidemic in France. COVID-19 Outbreak Assessment. EPIcx Lab, 15.

Donnelly, N., \& Proctor-Thomson, S. B. (2015). Disrupted work: Home-based teleworking (HbTW) in the aftermath of a natural disaster. New Technology, Work and Employment, 30(1), 47-61. https://doi.org/10.1111/ntwe.12040

Government Communication Office. (2020). Slovenia declares coronavirus epidemic. Retrieved 18 July 2020, from https://www.gov.si/en/news/2020-03-12-slovenia-declarescoronavirus-epidemic/

Okubo, T. (2020). Spread of COVID-19 and Telework: Evidence from Japan". Covid Economics (2020.6. 26) Https://Cepr. Org/Content/Covid-Economics-Vetted-and-RealTime-Papers-0 Please Direct Any Requests or Inquires to the Contact Information Provided below in Advance. 
Podgornik, N. (2020). Prepoznavanje in preprečevanje izgorelosti na delovnem mestu. In A. Raspor \& M. Nežič (Eds.), S skrbjo za sodelavce do boljših rezultatov podjetja (1.th, pp. 1-14). Dolga Poljana: Perfectus, Svetovanje in izobraževanje.

World Health Organization. (2020). Coronavirus disease (COVID-19). Master's Thesis in Work Life Studies. School of Health, Care and Social Welfare. 